研究論文

\title{
実験室における合体プラズマの二次元MHD シミュレーション - 兴の動的振る舞いについて -
}

渡辺智彦, 林 隆也, 佐藤哲也

核融合科学研究所理論・シミュレーション研究センター

\section{Two-dimensional MHD Simulation of Merging Plasmas in Laboratory Experiments - Focusing on Its Dynamic Behaviors-}

\author{
WATANABE Tomohiko, HAYASHI Takaya and SATO Tetsuya \\ Theory and Computer Simulation Center, National Institute for Fusion Science, \\ Toki 509-5292, Japan
}

(Received 27 January 1999 / Accepted 13 May 1999)

\begin{abstract}
プラズマ合体実験に関する二次元MHDシミュレーションを行い、弚れらの結果を主として動画像 を用いて解析した，产の結果、(1)スフェロマック合体時に発生するプラズマ流による圧力構造の形 成過程、(2)合体過程における磁力線のトポロジー変換と光の運動、(3)MRX実験で見られた磁気島 の形成過程、等の樣子が明解に示された .

Computer animations resulted from two-dimensional magnetohydrodynamic simulations of plasma merging have reproduced dynamic behaviors found in laboratory experiments. Specifically, the following features have been clearly shown, that is, 1) formation process of pressure profile by an induced plasma flow during counterhelicity merging of spheromaks, 2) topology change of field lines and their toroidal motion, and 3) magnetic island formation in a diffusion region during co-helicity injection.
\end{abstract}

\section{Keywords:}

magnetohydrodynamics, magnetic reconnection, simulation, spheromak, FRC

\section{1.はじめに}

核融合プラズマをはじめ、宇宙空間および天 体プラズマで見られるような、磁気流体(MHD) 方程式で記述され得るさまざまな巨視的プラズ マ現象において、磁気リコネクションが重要な 素過程であることが認識されて久しい[1-3] . 中 でも、磁気リコネクションによって磁力線のト ポロジーが変えられるために、トポロジーの異 なる最小磁気エネルギー状態へ磁場配位が緩和 できること、また、リコネクションに伴って磁 気エネルギーからプラズマの熱および運動エネ ルギーへの変換が起こること、等が指摘されて
いる（例えば文献[4-6]）。これらは非線形磁気 流体現象を考察する際の重要な指針となってい る。

実験室における磁気リコネクションの例とし ては、トカマクでの鋸歯状振動現象が古くから 知られているが、磁気リコネクションの物理機 構の解明を主目的とした実験は意外と少なく、 Yamada、Ono等による一連のプラズマ合体を用 いた実験[7-11]が近年注目を集めている．TS-3 (the Tokyo University Spherical Torus No.3) 装置 を用いた実験では[7,8]、二つの同一のスフェロ マックを合体させる同極性合体の結果、初期の 
スフェロマックのもつポロイダル磁場同士がつ なぎ変わり、単一のスフェロマックが形成され た。一方、反平行のトロイダル磁場を持つスフ エロマックを合体させる逆極性合体では、ポロ イダル磁場がつなぎ変わるだけでなく、双方の 卜ロイダル磁場が打ち消し合って、磁場反転配 位(FRC) が形成された .この時、トロイダル磁 場のエネルギーが最終的にはプラズマの熱エネ ルギーに変換されるため、効率的なプラズマ加 熱が起こる。

一方、磁気リコネクションを伴う強い非線形 現象を理論的に解明するために、1970年代後半 から数多くの計算機シミュレーションが行われ てきた[2,3] . 特に、プラズマ合体実験と似通っ た磁場配位をもちいて、以前から磁気島合体の シミュレーションが行われており[3,12]、現在で もさらに高精度の解法が試みられている[13] . これらのシミュレーションでは、リコネクショ ン率の抵抗依存性、散逸領域の形状、リコネク ションに伴うジェットの形成などに焦点があて られ樣々な結果が得られている．しかし、実験 の進展に伴い、実験により即した配位でプラズ マ合体と炎れに伴う磁気リコネクション過程を 理論的に検証することが必要となった．乥こで 我々は、TS-3装置の実験で見られたスフェロマ ックの合体過程をMHDシミュレーションによっ て再現し、光の合体機構の解明を試みた $[11,14$, 15] .シミュレーションにおいても実験と同樣に、

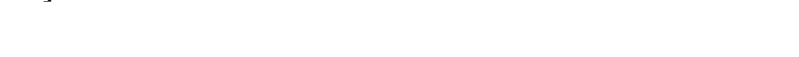
エロマックとFRCが形成された . また、実験で も示唆されているように、逆極性合体で結合し た磁力線がトロイダル方向の強いプラズマ流を 生み出しながら振動する現象が見られた．しか し、合体に要する時間は同極性と逆極性の場合 で同程度であり、逆極性合体が3倍ほど速く進行 するという実験結果は再現できていない．これ は、逆極性合体の場合MHDモデルでは取り扱え ない、二流体効果や粒子運動論的効果が働いて いるため、と考えられている .

TS-3実験の結果を踏まえて、さらに磁気リコ ネクションの物理過程のみに焦点をあてた実験 が、プリンストン大学プラズマ物理研究所の MRX (Magnetic Reconnection Experiment) 装置を 用いて行われている[9-11] . MRX装置は真空容 器内に一対のフラックスコアコイルを持ち、プ ラズマ中のトロイダル・ポロイダル両磁場成分 を変化させることができる . 主にポロイダルコ イル電流を減少させて、セパラトリックス点を 経てコイルに向かうプラズマ流を誘起し、リコ ネクションを起こす実験をpullモードと言い、 光の逆をpush モードと呼ぶ. MRXの初期の実 験では、pullモードで、かつ、二つのフラック スコアコイルから反平行のトロイダル磁場を与 える(counter-helicity injection)オペレーションを 行った場合には、リコネクションが駆動される とともにY字型の電流層が形成された . 一方、

平行なトロイダル磁場を与える co-helicity injectionでは、コイルの間にO点を持つ磁気島が 形成されるという結果が得られた最近我々は、

この現象を解明するためにMRX配位でのTaylor 解の解析およびMHDシミュレーションを行った [16,17] . その結果、co-helicity injectionの場合に は、磁気島を持つ解と持たない解がともにTaylor 解の最小エネルギー状態を表すブランチ上に存 在し、磁気へリシティの増加に伴って磁気島を 持つ解へと平衡配位が遷移することで実験結果 が説明されることが示された[16] .また、 counter-helicityの場合には、最小エネルギー状態 で磁気島を持つTaylor解が存在しないことから、 磁気島は発生せずに電流層が形成されると理解 できる．さらに、pushモードでは無次元化され た磁気へリシティが減少していくため、配位は 真空解に近づいていき、磁気島は形成され得な いことも指摘されている[17] .

本論文で、我々は、上述のTS-3およびMRX実 験を対象としたMHDシミュレーションで得られ た動画像を光れ光れ 2 節および 3 節で紹介し、 磁気リコネクション実験に伴って現れる動的現 象について考察する．主な結果は文献 $[15,16] に$ 詳述されているが、光れらを動画像として表現 することで、読者にはより直截的な現象の理解 が可能となるであろう . 2.1 および 3.1 節では、 TS-3、MRX、光れ光れを対象としたシミュレー ションモデルを示し、3.2 節でMRX配位での Taylor解について述べる. 光して、2.2 節ではス フェロマック合体の、3.3 節ではMRXのシミュ レーション結果を示し、最後に結果をまとめる .

\section{2. スフェロマック合体のシミュレーション}

\section{1 シミュレーションモデル}

ここでは、完全導体壁で覆われた円筒状のシ ミュレーション領域を設定し、軸対称性を仮定 して二次元のポロイダル面内で計算を行なう . TS-3実験では傾斜モードなどの成長を抑えて対 称性のよい合体が実現されている．一方で、理 想MHDモデルでは、FRCやスフェロマックなど のコンパクトな配位が、傾斜モードやシフトモ 
ードに対し不安定になりやすいことが知られて いる.ここでは、关れらのモードとプラズマ合 体の競合過程よりも、むしろ合体の物理過程光 のものに焦点をあてるために二次元の仮定を用 いている.シミュレーションを行う円筒の半径 を1として長さの単位に取り、防向の長さを光 の4倍に設定した（Fig.1参照）．このポロイダ ル面をr方向289、z方向1153の一樣な空間格子に 分割し、空間微分には二次の中心差分、時間積 分には四次のRunge-Kutta-Gill法を用いてシミュ レーションを行った . また、密度を1として一樣 におき、初期のトロイダル磁場の最大值が1.1と なるように無次元化を行った.初期磁場配位は、

半径 0.5 のHillの球形渦で表されたz $= \pm 0.75$ に中 心をもつ二つのスフェロマックと、㫕れらを包 む外部磁場で与えられる.初期条件の詳細は文 献[15]を参照されたい. 解くべき支配方程式は 以下のとおりである .

$$
\begin{aligned}
& \frac{\partial \rho}{\partial t}=-\nabla \cdot(\rho v) \\
& \rho \frac{d v}{d t} \\
& \frac{\partial B}{\partial t}=-\nabla \times E \\
& \boldsymbol{E}=-\boldsymbol{v} \times \boldsymbol{B}+\eta \boldsymbol{j} \\
& \Phi=2 v\left[e_{i j} e_{i j}-\frac{1}{3}(\nabla \cdot v)^{2}\right] \\
& e_{i j}=\frac{1}{2}\left(\frac{\partial v_{i}}{\partial x_{j}}+\frac{\partial v_{j}}{\partial x_{i}}\right)
\end{aligned}
$$$$
=-\nabla p+\boldsymbol{j} \times \boldsymbol{B}+v\left[\nabla^{2} \boldsymbol{v}+\frac{1}{3} \nabla(\nabla \cdot v)\right]
$$$$
\frac{1}{(\gamma-1)} \frac{d p}{d t}=-\frac{\gamma}{\gamma-1} p \nabla \cdot v+\eta j^{2}+\phi
$$

ここで、j、E、 $\boldsymbol{D} 、 e_{i j}$ は次式で与えられる .

$Y 、 V 、 \eta$ は、光れ光れ、比熱比 $(=5 / 3) 、$ 粘 性率 $\left(=10^{-4}\right)$ 、抵抗率 $\left(=10^{-4}\right)$ を表し、これらの值 は空間的に一樣とした .また、のは粘性散逸関 数を、 $e_{\mathrm{ij}}$ は歪み速度テンソルを示している.他 の記号は標準的な表記に従った .ただし、ここ で紹介するシミュレーションでは密度は一定と 近似して、(1)式は解いていない，密度の時間発 展を追跡する計算も行っているが得られた結果 に本質的な相違は見られなかった[15] .

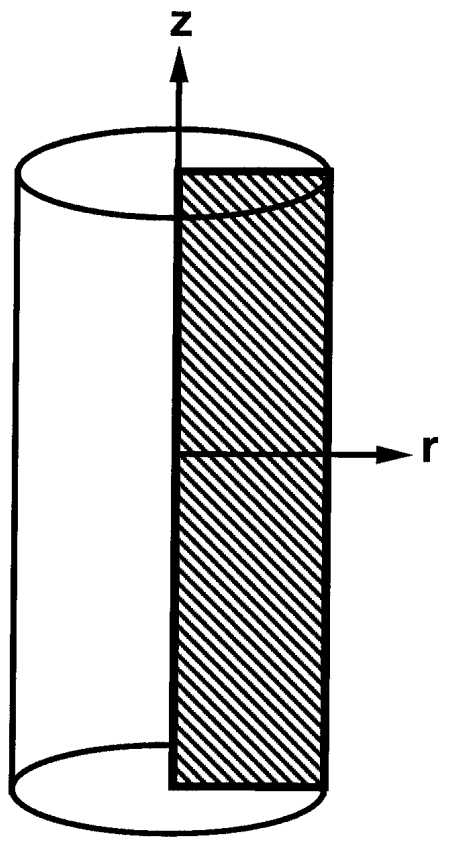

\section{$\square$ Perfect Conducting Vessel 2-D Simulation Domain}

Fig.1 スフェロマック合体のシミュレーション モデルの模式図 . 影のついた領域がシミュレー ションを行うポロイダル面に対応[14] .

Schematic plot of a simulation model of spheromak merging. Shaded region corresponds to the simulation domain [14].

\section{2 シミュレーション結果}

ここでは、スフェロマック合体のシミュレー ション結果を動画を用いて紹介する Anim.1に、

同極性および逆極性合体のアニメーションを続 けて示している.動画の右側にはポロイダル磁 束 $\boldsymbol{\Psi}$ 等高線図と圧力分布のカラーマップを表 示し、左側にトロイダル磁場分布をカラーマッ プで示している．赤色は正、青色は負のトロイ ダル磁場に対応し、中間の強度が緑色がかって 表示されている. 右側の図では、セパラトリッ クス磁気面の内側の領域のみでせを表示してい る。

動画には、はじめに同極性合体の結果が示さ れている.シミュレーションを開始すると、二 つのスフェロマックは同じ向きのトロイダル電 流を与えられているので、互いにローレンツカ で引き付け合い、 $\mathrm{z}=0$ の面に近づいていく $t=7$ $\mathrm{T}_{\mathrm{A}}$ すぎに、磁気リコネクションが発生し、スフ エロマックは合体を始める .ここで、 $\mathrm{T}{ }_{\mathrm{A}}$ はア ルヴェン伝播時間を示している.二つのスフェ ロマックの間に薄い電流層ができ、時間の経過 
とともに次々と磁気面がリコネクションを起こ し、合体が進行していく樣子がうかがえる .こ の場合、スフェロマックの合体は、 $t=25 \mathrm{~T}_{\mathrm{A}}$ ま でに完了し、z方向に長く伸びたスフェロマック が形成された 。

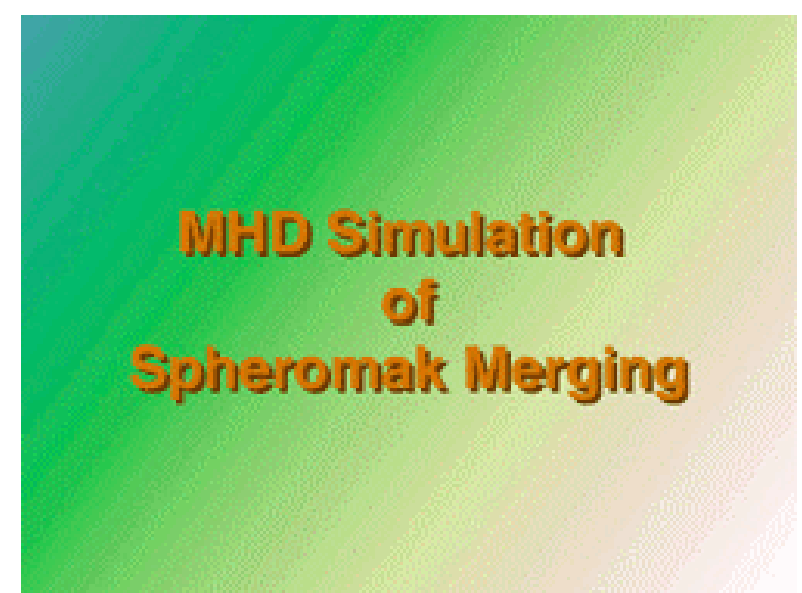

Anim.1 スフェロマック合体のシミュレーショ ン結果 .はじめに同極性合体の結果が表示され、 次に逆極性合体のシミュレーションが示される． 動画の左側にトロイダル磁場のカラーマップ(赤 は正、青は負の成分に対応) を、右側に圧力の カラーマップとポロイダル磁束の等高線図を示 した .ここで、ポロイダル磁束はセパラトリク ス磁気面内部でのみ表示されている .

Simulation results of co- (first) and counter(second) helicity merging of spheromaks. Toroidal field profile is shown in left using a color map from blue (negative) to red (positive). Right panel indicates pressure (color) and poloidal flux contour inside of the separatrix surface.

次に逆極性合体の場合を見てみよう．この場

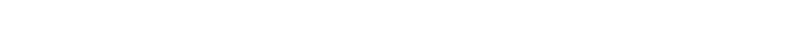
イダル磁場を持っている．逆極性の合体が進む につれて、反平行なトロイダル磁場は互いに打 ち消し合い、最後には消滅する樣子がうかがえ る. 光して合体後には、トロイダル磁場を持た ない、いわゆるFRCが形成されている．一方、 先に見た同極性合体では合体前とほぼ同程度の トロイダル磁束が残っている．したがって、同 極性合体に比べ、逆極性合体の場合は、多量の トロイダル磁気エネルギーが解放されることが わかる.また、合体していない磁気面の周りで、

トロイダル磁場が一時的に反転する樣子が見て とれる．反転したトロイダル磁場は、振動しな がら关の極性を変えて減衰していく．このよう なトロイダル磁場の反転はTS-3実験でも観測さ
れており、光の原因は、リコネクションで発生 したシアを持つ強いトロイダル流と磁場が相互 作用してアルヴェン振動を起こすためと考えら れる.

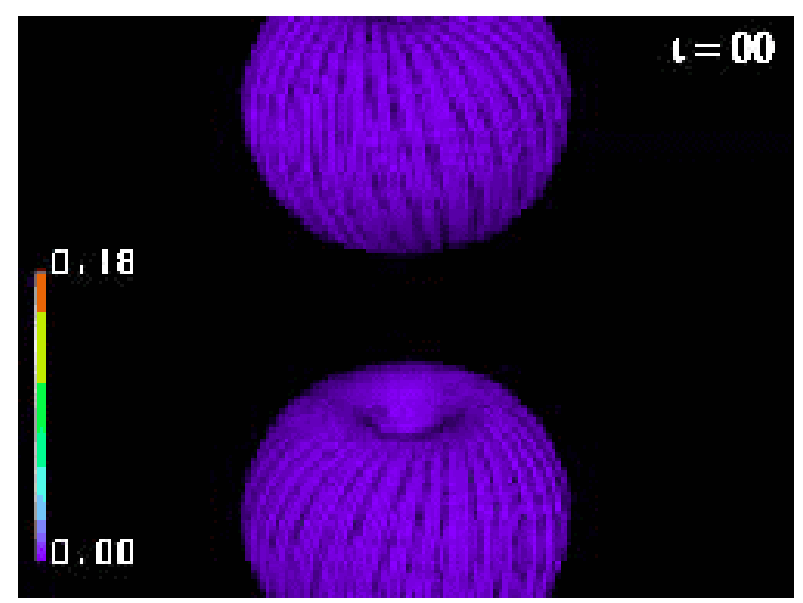

Anim.2 逆極性スフェロマック合体における磁 力線の三次元構造 . 弚れ艺れの磁力線は弚の場 の圧力に応じて色づけされている．合体途中で 磁力線ループがトロイダル方向に振動する樣子 がわかる .

Dynamic behavior of magnetic field lines colored by local pressure in three-dimensional space during counter-helicity merging of spheromaks. One can see toroidal oscillations of field-line loops.

磁力線構造を三次元的に表示することで、先 述したトロイダル磁場の反転と磁力線のダイナ ミクスを、より明確に、乥してより直截的に見 ることができる．Anim.2に逆極性合体における 磁力線の変化の樣子を三次元的に表示した . こ こで、磁力線は光の点の圧力に応じて色づけさ れている.初期に逆のへリックスを持つ二つの スフェロマックの磁力線が、合体にともなって つなぎ変わり、さらに内側の磁力線同士が結合 しはじめるようすがわかる. 弚して、 $t=15$ から 20T ${ }_{A}$ 頃には、トロイダル方向へ引き延ばされた ループ状の磁力線が見られ、さらに光れらが卜 ロイダル方向に振動する樣子が見て取れる．最 後には、正味のトロイダル磁束を持たない、FRC が形成されていることが磁力線構造からもわか る.また、この動画を詳しく見ると、外側と内 側の磁力線のループが光れ独立に振動して いることがわかる.これは、光の振動を引き起 こしているトロイダル流が動径方向に強いシア を持っていることを示している．

TS-3実験では、上述のトロイダル磁場の振 動・反転やトロイダル流の分布、イオン温度の 
上昇などか詳しく測定されている[] . 乥こでは、 Anim.1およびAnim.2で見られたような多数回の 振動は見られず、トロイダル流の空間分布もゆ るやかで、Anim.2でみられたような内側と外側 の磁力線ループが逆向きに運動する程の速度シ アは観測されていない．また、逆極性合体に際 して解放された磁気エネルギーの大部分が、直 接、イオンの運動エネルギーに変換され、イオ ンの加速および加熱を起こしている[]].こうし た実験とシミュレーションの相違は、粘性等の パラメータの違いによるのかもしれない.より 定量的な比較を行うにはイオンの有限ジャイロ 半径効果等を取り入れたモデルを用いる必要が あると考えられているが[7]、ここで示したシミ ユレーション結果は実験から導かれた sling shot モデル[] $]$ と矛盾のないものであり、逆極性合体 のMHD的振る舞いをよく表している .

Anim.1に戻り、逆極性合体における圧力分布 の変化の樣子を見てみると、合体の最中にリコ ネクション電流によりジュール加熱が増大し、 リコネクション点付近で局所的に圧力が上昇し ていることがわかる．关の増加した熱エネルギ 一が、合体した磁気面に沿って広がっていき、8 の字型の圧力分布が一時的に形成される .ここ では熱伝導の効果を採り入れていないにも関わ らず、最終状態では磁気面に沿った圧力分布が きれいに形成されていることは注目に值する． 乥して、圧力勾配とローレンツカのほぼ釣り合 つた状態が実現されている .この圧力分布の形 成過程は、プラズマ流による熱輸送で説明され る.まず、磁気リコネクションにより、リコネ クション点から吹き出すプラズマ流が作られる . 乥のプラズマ流は、リコネクション領域から離 れると、流れの向きが変わり、磁気面に沿った プラズマ流ができる．关の流れによって熱エネ ルギーがリコネクション点付近から磁気面全体 に輸送され、磁気面に沿った圧力分布が自発的 に形成される .

また、合体の最中にスフェロマックのz方向 へのバウンス運動が見られるが、これはリコネ クション点付近で局所的にジュール加熱により 圧力が増加してスフェロマックが押し返され、 乥してまたローレンツカで引き合うとために起 こると考えられる.これに応じてリコネクショ ン電流、つまり、リコネクション率が増減する． 実際、比熱比 $\mathrm{Y}$ を $3 / 2$ から $7 / 3$ まで変化させて、 いくつかのシミュレーションを行ってみると、 Y が大きくなるにつれて合体により長い時間が かかること、また、リコネクション電流がより
弱くなることがわかっている[15] .このことは、 磁気リコネクションによる局所的な圧力上昇が スフェロマック全体の運動に影響すること、ま た磁気リコネクション率が合体時間を決める主 たる要因となることを示している .

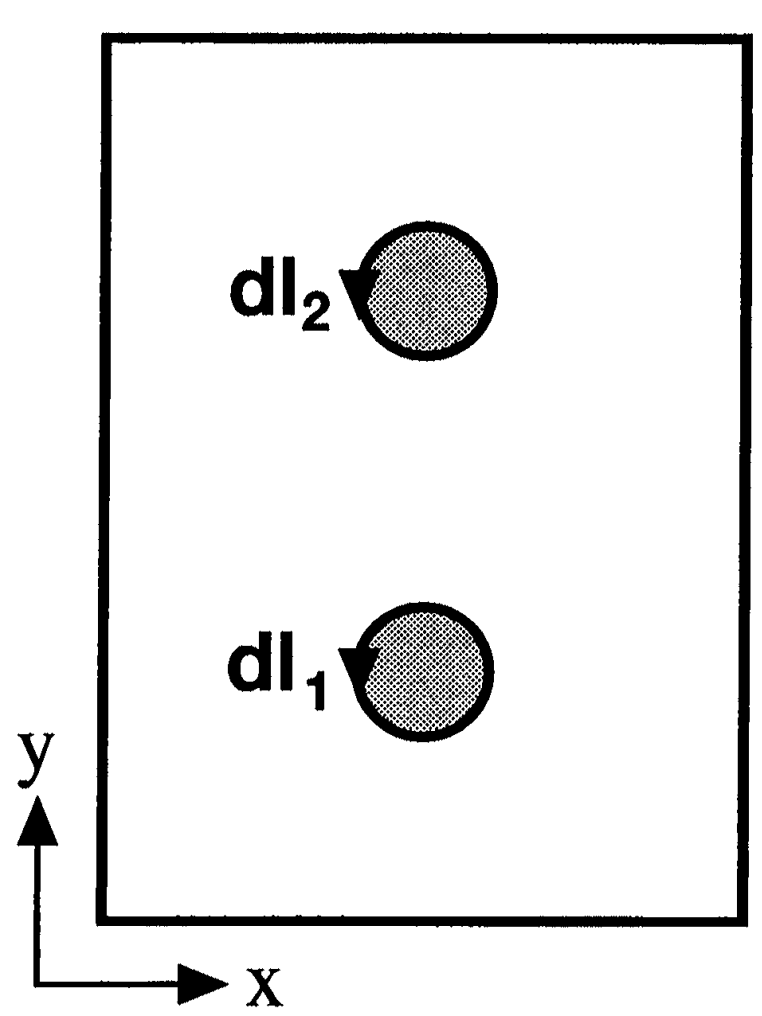

Fig.2 MRX実験の数值モデルの模式図 . 系内の 二つの円がフラックスコアコイルの断面を示し ており、光れらを取り巻く積分経路は(15)式で 定義されたへリシティの計算に用いられる[17] .

Schematic plot of a numerical model of MRX. Integral contours around two circles which represent cross-sections of flux-core coils are used for calculation of helicity given in Eq.(15) [17].

\section{MRXのシミュレーション}

\section{1 シミュレーションモデル}

MRX装置をモデル化して、 $-1<\mathrm{x}<1 、-1.4<\mathrm{y}$ < 1.4 の領域に完全導体で囲われたプラズマを考 える.ここでトロイダル効果は無視し、系はz方 向に対称とする(z方向がトロイダル方向に対応) . 半径 $r_{\mathrm{c}}=0.2$ をもつ一対のフラックスコアコイル を光れ光れy $= \pm 0.6$ に設置する (Fig.2参照) . コイル上での境界条件を与えやすくするために、 コイル表面に計算格子が一致するように数值的 に生成された一般座標を用いてシミュレーショ ンを行う.上述の (1) - (4) 式の時間発展を光 
の格子上で追跡するが、ここでは、（4）式をポ ロイダル、トロイダル成分に分けて、さらにポ

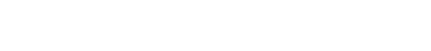

$$
\begin{aligned}
& \frac{\partial \Psi}{\partial t}=-E_{z} \\
& \frac{\partial B_{z}}{\partial t}=-\nabla \times \boldsymbol{E}_{\perp}
\end{aligned}
$$

ここで、 $j 、 E 、 B$ は次式で与えられる .

$\boldsymbol{j}=j_{z} \hat{z}+j_{\perp}=\hat{z} \nabla^{2} \Psi+\nabla B_{z} \times \hat{z}$

$\boldsymbol{E}=E_{z} \hat{z}+\boldsymbol{E}_{\perp}=-\boldsymbol{v} \times \boldsymbol{B}+\eta \boldsymbol{j}$

$\boldsymbol{B}=B_{z} \hat{z}+\nabla \Psi \times \hat{z}$

ここでは $\mu=j / B=-1$ 、系内に蓄えられたポ ロイダル磁束を $\Psi_{0}=1$ とした時の（次節で導か れる) Taylor解を初期条件とし、初期に微小な 速度擾乱を加え、コイル上に弱い電場を与えポ ロイダル磁束を時間的にゆっくりと減少させて、 磁場配位の変化を調べる．密度の初期分布は一 樣とする . 速度は境界上で0とし、真空容器壁に あたる外側境界は完全導体、フラックスコアコ イルに対応する内側境界は $E_{\mathrm{z}}= \pm 0.01$ とする(こ こで+記号はpullモード、-(はpushモードに対応) . $E_{z}$ の符合以外の条件はpull、pushモードで共通と した . 電場のポロイダル成分はコイル上で0とす る. また、粘性率 $\mathrm{v}=10^{-3}$ 、比熱比 $\mathrm{Y}=5 / 3$ と した。

上述のコイル上での電場の境界条件は、MRX 実験でのプラズマ放電および配位形成の後の pullやpushオペレーションの段階をモデル化した ものである . MRXのpullモードco-helicity実験で は、トロイダルコイル電流回路を短絡し、光の 電流の時間変化がポロイダルコイルの光れに比 ベ緩やかになっている状態で、ポロイダルフラ ックスがコイル内に引き込まれて磁気島が形成 されるので、ここで用いたコイル電場のモデル は単純だが妥当なものであろう.

\subsection{MRX配位でのTaylor解}

シミュレーション結果の紹介に進む前に、 MRX配位におけるTaylor解について触れておく ことが有益であろう.ここで考えているような 方向に対称性のある系において、 $j+\mu \boldsymbol{B}=0 \quad(\mu$ は定数) を満たす解は、

$$
\nabla^{2} \Psi+\mu^{2} \Psi=0
$$

なる式を、系内に $\Psi_{0}$ のポロイダル磁束が蓄え られているという境界条件の下に解いて得られ る. また、ここで考えているような多重連結領
域内でゲージ不変な磁気へリシティは次のよう に定義される[6,16] .

$$
K \equiv \int \boldsymbol{A} \cdot \boldsymbol{B} d x d y-\sum_{i} \Psi_{0} \oint \boldsymbol{A} \cdot d \boldsymbol{l}_{i}
$$

ここで周回積分はFig.2で表されている経路を とる .

(14)式を数值的に解いた結果、 $\mu=0$ から連 続的に解が存在し (Fig.3の実線) 、 $|\mu|=3.2$ 付 近でエネルギー、ヘリシティともに発散してい くことがわかった .この時 $\mu$ は

$$
\nabla^{2} f+\lambda^{2} f=0
$$

という固有值方程式で、内部および外部境界 でf $=0$ とした固有値問題の最小固有值入， に対応 する．つまり、 $\boldsymbol{\psi}$ は、 $\mu$ が最小固有值 $\lambda_{1}$ に 近づくにつれて、弚の対応する固有関数 $f$ に近 ブいていくことがわかる . また、与えられた に対して解 いときは真空解と同樣に8字型のセパラトリック スを持つ配位が、 $\mu$ が大きくなるに連れてプラ

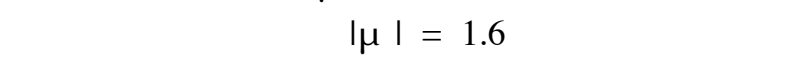
アコイル表面にセパラトリックスを持つ磁気島 が現れ、 $\mu$ が増加して最小固有值に近づくとと もに磁気島が大きくなり、系全体をおおってい くことがわかっている[16] .

以上の結果をMRXでのco-helicity injection実験 に対応させて考えてみる．MRXのプラズマは低 $\beta$ であるので、放電後、pullモードでポロイダ ル磁束を減少させ始める(コイル表面で正の $E_{\mathrm{z}}$ を 与える)前に、配位は、 $|\mu|<1.6$ のプラズマ電流 が小さく磁気島のないTaylor状態にあると考え られる .ループ電圧による時間変化がアルヴェ ン時間より十分緩やかな場合、系の時間発展は ほぼ平衡状態に沿って変化するであろう．コイ ル電流を変化させてポロイダル磁束を減少させ ると、誘導電流がプラズマ中に流れる．したが って、系内に蓄えられているポロイダル磁束で 無次元化した磁気へリシティは増大することに なる．言い換えると、师仹増大し、プラズマ電 流の寄与がコイル電流に比べて徐々に大きくな っていくので、pullモードの場合、自然に磁気 島が現れてくると予想される．一方、pushモー ドの場合は、逆にポロイダル磁束は増大し、無 次元化した磁気へリシティは減少していく.し たがって配位は真空解に近づいていくので、push モードでは磁気島は現れないと予想される．こ の予想は最近のpushモードの実験結果と一致し ている．さらに、系の対称性を考えると、 counter-helicityの場合には、 $|\mu|<\lambda_{1}$ で磁気島を 
もつTaylor解は存在しないことがわかる．この ため、counter-helicity injectionでは磁気島は発生 しにくいと考えられる .

以上の議論はトロイダル方向への対称性をあ らかじめ仮定して行われている．プラズマ電流 が大きい場合には、ポロイダル断面の形状や卜 ーラスのアスペクト比によっては、有限のトロ イダルモード数を持つ三次元的なモードが不安 定になる可能性も有り、より完全な議論を行う には、三次元でのTaylor解の解析が必要である . しかし、これまでのco-helicityのMRX実験では 弚のような三次元的な不安定モードの成長は確 認されていないことから、少なくともプラズマ 電流の小さな磁気島発生の初期段階では上述の 議論で十分であろう.

\section{3 シミュレーション結果}

Anim.3は、co-helicity injectionで、かつ、pull モードの場合のシミュレーション結果であり、 乥こには、ポロイダル磁束の等高線図と $j_{z}$ のカ ラーマップが示されている . わかりやすくする ために、コイル間の磁気島が発生する領域付近 を拡大して表示した.時間0から50 T A $_{\text {A でを } 0.1}$ T ${ }_{\mathrm{A}}$ ごとにプロットしている．また、コイル付近 では不純物が多いと予想されることから、次式 で表される抵抗モデルを用いたシミュレーショ ンを行った。

$$
\eta=\eta_{0}\left[1+C_{\eta} \exp \left\{-\left(r-r_{\mathrm{c}}\right)^{2} / r_{\mathrm{c}}^{2}\right\}\right]
$$

ここで、rはより近い方のコイル中心からは かった距離を示し、また、 $\eta_{0}=5 \times 10^{-4} 、 C_{\eta}=$ 20 とした . MRXのco-helicity実験の場合には、 異常抵抗をともなうような電流層が形成されな いので、このような抵抗モデルは妥当なもので

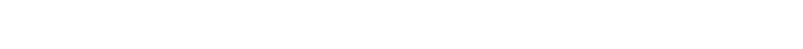
リコネクションが誘起されるとともに、プラズ マ中に誘導電流が流れて磁場分布が変化してく る. 弚して $t=20 \mathrm{~T}{ }_{\mathrm{A}}$ 以降に、コイル間に小さな 磁気島が現れ、散逸しながらも徐々に成長して いく.この磁気島発生過程は、実験結果の動画 解析と非常によく一致している[18] . 先述のMRX のTaylor解の解析から予想されるように、時間

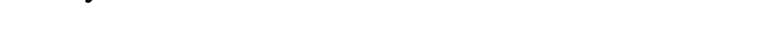
磁気島はさらに成長していき、系全体をおおつ ていく.

シミュレーションで得られた磁場分布から、 5T ${ }_{\mathrm{A}}$ ごとに系内に蓄えられているUの值で無次 元化した磁気ヘリシティとエネルギーを計算し、 Taylor解と比較してプロットしたものがFig.3で ある．この図を見ると、pullモードでは、時間 とともにへリシティとエネルギーがほぼTaylor 解に沿って増加していくことがわかる .

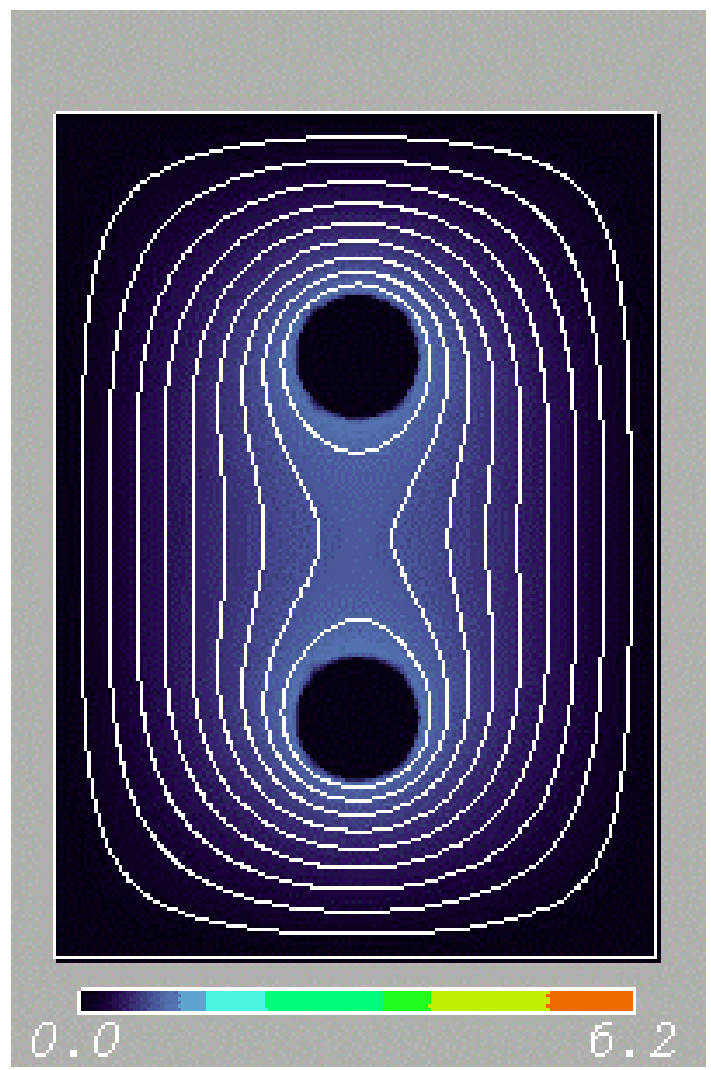

Anim.3 MRXでのco-helicity実験のpullモードの シミュレーション結果．ポロイダル磁束の等高 線図とトロイダル電流密度をカラーマップで示 している. 時間 $t=20 \mathrm{~T}$ A過ぎからコイル間に磁 気島か現れはじめ、徐々に成長していく.

Simulation result of pull mode in MRX with cohelicity injection, where color represents toroidal current profile. Contour lines correspond to magnetic field lines. A magnetic island appears after $t=20$ $\mathrm{T}_{\mathrm{A}}$, and then, grows slowly.

ここに示したpullモードのシミュレーション では、磁気島発生の初期段階において、小さな 磁気島が系の中央で発生するが、これはコイル 近傍で抵抗が大きいので、誘導電流が中心領域 に集中して流れるため、と理解される．実際、

一樣な抵抗モデルを用いた場合、磁気島はAnim.3 で見られるようには発生せず、光れ光れのコイ ル表面で磁気島がまず発生し、光れらが合体し た後大きく成長していった[16]．しかしいずれ の場合も、磁気エネルギーとへリシティはTaylor 解にほぼ沿って時間発展し、二つのコイルの間 で磁気島が大きく成長した。また、Anim.3の最 
後 50T ${ }_{\mathrm{A}}$ に見られる磁気島は、一樣な抵抗を用 いた場合のほぼ等しい磁気エネルギーを持つ $t=$ $40 \mathrm{~T}{ }_{\mathrm{A}}$ での磁場分布と、よく似通った分布を示 している. 以上の結果は、磁気島が初期に形成 される位置や数などの配位の微細構造は抵抗モ デルに依存するが、系のグローバルな発展は抵 抗モデルによらずTaylor 解に沿った平衡配位の 変化で説明できるということを示唆している .

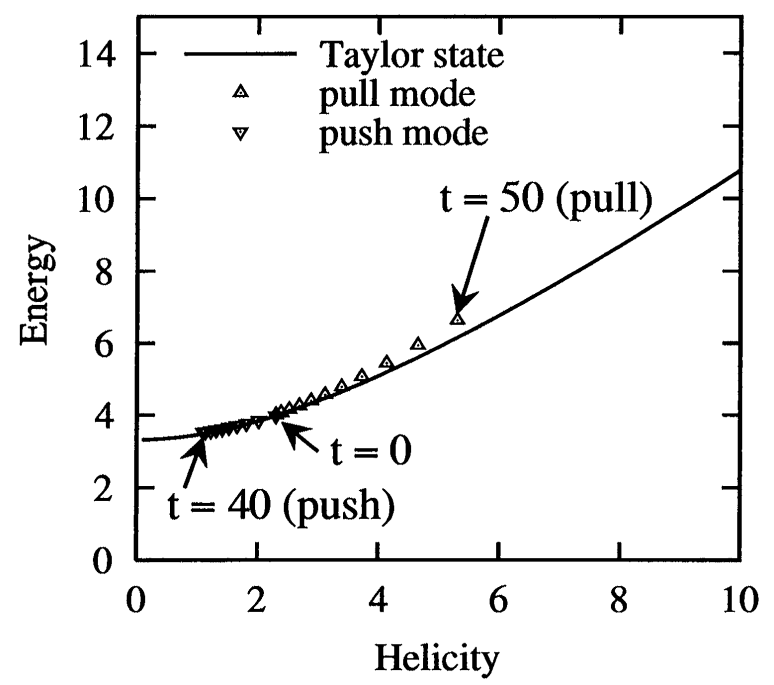

Fig.3 MRX配位におけるTaylor解 (実線) と、

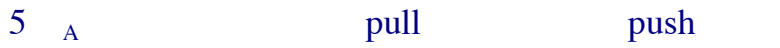
モードのシミュレーション結果[17] .

Time evolution of energy and helicity obtained at every $5 \mathrm{~T}_{\mathrm{A}}$ from pull and push mode simulations. Solid line shows the Taylor state [17].

一方、pushモードの場合は、無次元化された エネルギー、ヘリシティともに減少し、Taylor 解に沿って徐々に真空解に近づいていく

(Fig.3） .このpushモードのシミュレーション 結果を、 $t=0$ から40 T ${ }_{\text {A }}$ かで、 Anim.3 アニメーションで示したものがAnim.4である . ここで、電流のカラーマップはAnim.3の場合と は逆に負の $\mathrm{j}_{\mathrm{z}}$ が赤く色づけされている．つまり、 pushモードで出増えていくのに伴って、初期 の平衡配位をつくる電流とは逆向きのプラズマ 電流が誘導されている.Anim.4のはじめに少し pullされているように見えるのは、有限の抵抗 と初期平衡配位の電流によりポロイダル磁場が わずかに散逸するためである . 時間の経過とと もに、セパラトリックス点近傍でリコネクショ ン電流がピークするが、全体の配位は真空解に 近づいていく．このように、pushモードでは磁 気島は発生せず、X字型の電流分布が形成され
ることがわかる．また、Fig.3に見られるように、 push モードの場合 $t=40 \mathrm{~T}{ }_{\mathrm{A}}$ 附近では無次元化 した磁気へリシティ、エネルギーはともにほと んど変化しなくなる．一方で、電流密度はX点 で増大し続けるので計算の続行が難しくなるた め、 $t=40 \mathrm{~T}$ Aでシミュレーションを打ち切った ことを付け加えておく.

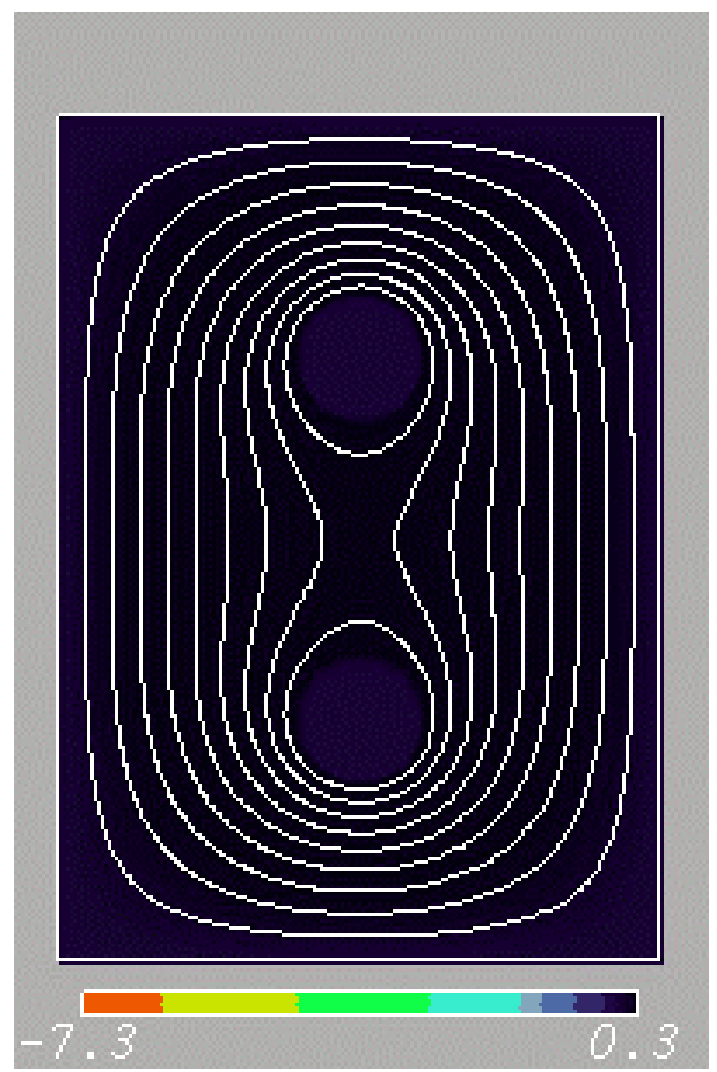

Anim.4 MRXでのco-helicity実験のpushモード のシミュレーションをAnim.3と同樣に表示した . この場合は、負のトロイダル電流がセパラトリ クス点でピークするが、配位は真空解に近づい ていき、磁気島の形成は見られない．

Same as Animation 3, but for push mode simulation. Since the configuration approaches to the vacuum solution, no magnetic island is formed, although negative toroidal current peaks at the separatrix point.

\section{4. まとめ}

ここでは、TS-3とMRXという二つの磁気リコ ネクション実験を対象としたMHDシミュレーシ ヨンを光れ光れ紹介した．关れらの結果を動画 像として表現することで、直截的な現象の理解 が可能となった . 特に、TS-3実験を想定した逆 極性スフェロマック合体のシミュレーションで は、リコネクション点近傍での圧力の増加と、 
光こから吹き出るプラズマ流による熱輸送、増 大した圧力勾配により引き起こされるバウンス 運動などの関連が示された．また、磁力線ルー プの三次元的な動画により、弚のトロイダル方 向への振動が、シア流を伴っていることが明ら かになった．MRX実験を対象としたシミュレー ションでは、pullモードの際に見られる磁気島 形成過程において、关の初期段階で小さな磁気 島が散逸を伴いながらも徐々に大きくなってい く樣子がよくわかった . また、実験結果の動画 [18] と対比することで、今後より定量的な実験 とシミュレーションの比較が可能となるであろ う.

また、この一連のシミュレーションを通じて、 グローバルな磁場配位と局所的な磁気リコネク ションの物理過程とが密接に関連して、系の発 展を担っていることがよくわかる.逆極性スフ エロマックの合体では、磁気リコネクション点 近傍で増大した圧力勾配が、磁気リコネクショ ン率を低下させて合体の進行を妨げ、また、光 の増加した熱エネルギーが磁気面に沿って輸送 されることで、圧力分布が形成されていく.方、MRXのシミュレーションでは、磁気島形成 という局所的な現象が、フラックスコアコイル によるプラズマ電流の誘導と Taylor緩和という よりグローバルな機構に依っていることがわか る。

MRX実験で見られた磁気島の発生は、一見す ると、ティアリングモード等の局所的な成長に よるのではないかと思われるかもしれない．し かし弚のためには、電流層が形成されることが 必要であり、さらに、有限の大きさを持つ磁気 島が電流層に沿った運動に対して安定に成長す る機構を考える必要がある.また、关の成長率 は抵抗等のパラメータに依存するであろう . 一 方、MRX実験のpullモードの結果では、樣々な 条件の下で、電流層は形成されずに磁気島が発 生し安定に成長する.このことから、ティアリ ング等による磁気島形成の可能性は低く、本論 文で考察したTaylor解に沿った磁場配位の遷移 による磁気島形成が有力と考えられる.

本論文では、プラズマ合体実験の二次元MHD シミュレーションで得られた動画像を紹介した が、こうした動画像解析は多次元のシミュレー ションに対してより有用であろう. 兴のために は、高速な三次元グラフィックス処理の可能な コンピュータが不可欠であり、光の方面の技術 の進展とともに、今後、より時間・空間分解能 の高い解析が行われていくであろう .

\section{参考文献}

[1] E.N. Paker, in Cosmical Magnetic Fields (Clarendon Press, Oxford, 1979).

[2] T. Sato and T. Hayashi, Externally Driven Magnetic Reconnection and a Powerful Magnetic Energy Converter, Phys. Fluids 22, 1189 (1979)

[3] D. Biskamp, Magnetic reconnection, Phys. Rep. 237, 179 (1993).

[4] T. Sato and K. Kusano, Nonlinear Driven Reconnection in the Reversed-Field Pinch, Phys. Rev. Lett. 54, 808 (1985).

[5] J.B. Taylor, Relaxation of Toroidal Plasma and Generation of Reversed Magnetic Fields, Phys. Rev. Lett. 33, 1139 (1974).

[6] J.B. Taylor, Relaxation and Magnetic Reconnection in Plasmas, Rev. Mod. Phys. 58, 741 (1986).

[7] Y. Ono, M. Yamada, T. Akao, T. Tajima and R. Matsumoto, Ion Acceleration and Direct Ion Heating in Three-Component Magnetic Reconnection, Phys. Rev. Lett. 76, 3328 (1996).

[8] Y. Ono, M. Inomoto, T. Okazaki and Y. Ueda, Experimental Investigation of Three-Component Magnetic Reconnection by Use of Merging Spheromaks and Tokamaks, Phys. Plasmas 4, 1953 (1997).

[9] M. Yamada, H. Ji, S. Hsu, T. Carter, R. Kulsrud, N. Bretz, F. Jobes, Y. Ono and F. Perkins, Study of Driven Magnetic Reconnection in a Laboratory Plasma, Phys. Plasmas 4, 1936 (1997).

[10] M. Yamada, H. Ji, S. Hsu, T. Carter, R. Kulsrud, Y. Ono and F. Perkins, Identification of Y-shaped and O-shaped Diffusion Regions During Magnetic Reconnection in a Laboratory Plasma, Phys. Rev. Lett. 78, 3117 (1997).

[11] M. Yamada, H. Ji, T.A. Carter, S.C. Hsu, R.M. Kulsrud, N.L. Bretz, F.C. Jones, Y. Ono, M. Katsurai, T.-H. Watanabe, T. Sato and T. Hayashi, in Proceedings of the 16th International Conference on Fusion Energy, Montreal, 1996 (International Atomic Energy Agency, Vienna, 1997), vol.2, p.253.

[12] T. Tajima, in Computational Plasma Physics: with Application to Fusion and Astrophysics (Addison-Wesley, Redwood City, 1989).

[13] C. Marliani and H.R. Strauss, Reconnection of Coalescing Magnetic Islands, Phys. Plasmas 6, 495 (1999). 
[14] T.-H. Watanabe, T. Sato, T. Hayashi and K. Watanabe, MHD Simulation of Coalescence Process of Spheromaks, J. Plasma Fusion Res. 72, 249 (1996).

[15] T.-H. Watanabe, T. Sato and T. Hayashi, Magnetohydrodynamic Simulation on CO- and Counter-Helicity Merging of Spheromaks and Driven Magnetic Reconnection, Phys. Plasmas 4, 1297 (1997).

[16] T.-H.Watanabe, T.Hayashi, T.Sato, M.Yamada and H.Ji, Modeling of Magnetic Island Formation in Magnetic Reconnection Experiment, Phys. Plasmas 6, 1253 (1999).

[17] T.-H. Watanabe, T. Hayashi and T. Sato, A magnetohydrodynamic model of MRX discharges, submitted to Proceedings of 9th International Toki Conference (JPFR series No.2, 1999).

[18] M. Yamada, H. Ji and MRX group, http://w3.pppl.gov/ mrx/ . 